ISSN 1112-9867

\title{
THE EVALUATIONS OF FACEBOOK AS AN EDUCATIONAL TECHNOLOGY TOOLS IN POLYTECHNIC'S ENTREPRENEURSHIP COURSES
}

\author{
M. M. Ali ${ }^{1, *}$, N. Hashim ${ }^{2}$ and A. Ibrahim ${ }^{1}$ \\ ${ }^{1}$ School of Technology Management and Logistics, College of Business, Universiti Utara \\ Malaysia, Sintok, Kedah, Malaysia \\ ${ }^{2}$ School of Business Management, College of Business, Universiti Utara Malaysia, Sintok, \\ Kedah, Malaysia
}

Published online: 10 November 2017

\begin{abstract}
Entrepreneurship is integrated into the curriculum structure designed for students studying subjects other than Business. The aim of this study was to evaluate the usage of Facebook as an educational technology tool in entrepreneurship course in TVET institution particularly in Polytechnic Malaysia. The 400 sample was selected randomly among the students from the Malaysian Polytechnic Institutions. Tool analysis using IBM-SPSS version 21. The constructs of Cronbach's alpha is 0.932 . The results supported. It shows the averages mean value scores for educational technology tools is on the approximate scale of 4.0 (3.93). Usages of Facebook as an educational technology tools onto entrepreneurship course was well received by Polytechnics' students
\end{abstract}

Keywords: Facebook usage; educational technology tools; entrepreneurship course; polytechnics; DoI theories.

Author Correspondence, e-mail: mazitapolytech@gmail.com doi: http://dx.doi.org/10.4314/jfas.v9i6s.60 


\section{INTRODUCTION}

\subsection{Background}

Under the 11th Malaysia Plan, the development of human resources through entrepreneurship has been identified as an important agenda to support the economic shift toward innovation and knowledge based activities. In accordance, Higher Education Institutions (HEI) need to be proactive in transforming their communication structure to be more flexible and entrepreneurial.

In addition, it needs to suit local needs but with global appeal to create an education system that is able to produce holistic, balanced and entrepreneurial individuals who would become job creators, in line with the First Thrust of Malaysia Education Blueprint 2015-2025 (Higher Education). HEI's entrepreneurship programs which are structured and holistic gives students the opportunity to generate income during their studies, aside from increasing their employability.

The Malaysian Polytechnics were seen to actively progress towards the government's aim and objectives. Among the efforts made are developing and offering courses based on various approaches namely innovation and entrepreneurial aspects, which require a high degree of cooperation, commitment and understanding with industrial sectors. In addition, an elected advisory panel from industry stakeholders was introduced to ensure the courses offered matches industry needs.

Social networking sites like Facebook have been issues which is showed many debate within the educational community. Whereas, the increasing number of educators knowing the powerful of social networking to participate students with their studies, others fear that such applications disturb and interrupt young people's engagement with 'traditional' education provision [23].

The Polytechnic Transformation Plan was aimed at building new capabilities in developing the nation's human resources to fulfill the new economic model needs, which is based on innovation and creativity. This is in line with the Second Thrust of the National Mission which is to raise the capacity for knowledge and innovation while nurturing 'first class mentality'.

Entrepreneurship as a subject in polytechnics aims to give students the exposure in 
developing their skills and interest in business. In this rapidly changing world, students need to be able to continually discover and explore opportunities if they are to thrive and progress after graduation. Some people are able to discover opportunities and successfully exploit them, something the student can aspire towards.

\subsection{Literature Review}

\subsubsection{Facebook as an Educational Technological Tools}

Many scholars view Facebook as educational technology tool [2, 4, 25]because of its constructive qualities such as enabling peer feedback, goodness of fit with social context and interaction tools [16]. In [5] broadly agree that it can be a useful educational tool, especially by providing active participation and collaboration because most Facebook users are between 18 and 25 years old, they mostly are higher education students.

The importance of SNSs in the activities daily of students of all ages has encouraged great enthusiasm amongst some educators. It has been demanded, such as, that social networking applications share many of the necessary qualities of good 'official' education technologies-permitting peer feedback and matching the social contexts of learning such as the school, university or local community [16].

\subsubsection{Importance of Entrepreneurship in Polytechnics}

Entrepreneurship is one of the modules under the Business Studies programs offered to all commerce students. Similarly, Entrepreneurship is also integrated into the co-curriculum structure designed for students studying subjects other than Business. A thorough review of the entrepreneurial studies curriculum was completed in 2006. New approaches and enterprising elements were embedded into the new curriculum to make the teaching, delivery and learning atmosphere more interesting and attractive to non-business recruits. The newly reviewed curriculum was officially implemented in June 2007. However, the course is an elective module for all non-commerce students.

Recognizing the significance of entrepreneurial education amongst students, Polytechnic Education Department under Ministry of Education Malaysia has made Entrepreneurship subject compulsory as an elective for Club/Society (DRK3002) and Entrepreneurship (DPB2012/DPB 2012) as a course in polytechnics across Malaysia.

Digital Entrepreneurship (DE) is a compulsory course, newly introduced in 2015 to students 
of all study programs. This course inculcates experience-based lessons where students are asked to operate an online business throughout the 13 weeks course period by implementing course contents. This course was introduced to prepare students with the skills to use digital platform in conducting business. It also offers knowledge and skills needed to develop individuals to be digital entrepreneurs where students are exposed to various online media, social media and other platforms used by digital entrepreneurs nowadays [3].

This is in line with the National Higher Education Strategic Plan 2011-2015 Phase 2 which focuses on efforts to make entrepreneurial education mainstream. This effort is to increase entrepreneurial skill amongst all students whom will contribute to the nation's economic progress. This plan also gave exposure and instilled entrepreneurial values and skills to university, polytechnic and community college students. It encompasses aspects of leadership, innovation, creativity, competitiveness, independence, ability to take calculated risk, ability to identify and create opportunities.

\subsubsection{Problem Statement}

Although Facebook was not originally designed for educational purposes, to date there has been little agreement on what some studies have stated about the potential of Facebook as a learning resource that enhanced the collaborative models of learning and cooperative learning which are connect students and educators, increase students' motivational level and create a more comfortable classroom environment [9, 15-17, 19].

While others have shown using such technology to elevate student engagement can foster positive intellectual and emotional learning attitudes, potentially enhance academic achievement and critical thinking skills [6]. Issues presently under debate are how Facebook can improve students' performance $[7,13,21]$. However, far too little attention has been paid to research about the Facebook advantages can be the educational technological tools in entrepreneurship course.

\subsubsection{Objectives}

The aim of this study was to evaluate the usage of Facebook as an educational technology tool in entrepreneurship course in TVET institution particularly in Polytechnic Malaysia. If we were to look back into the Malaysia Education Blueprint 2013-2025, Ministry of Education Malaysia (MOE) also stressed that entrepreneurship is one of the aspects under leadership 
skills. Entrepreneurship is linked to students' ability to take the initiative, to initiate and develop a business independently and is willing to invest with own capitals, aside from being driven to ensure that the business yields profit [20].

\section{METHODOLOGY}

\subsection{Design Study}

This study used a cross-sectional survey design using quantitative methods to collect data using surveyed by using questionnaires because an effective and practical way to get information is to use a survey method [1].

\subsection{Respondents}

The study population consisted of all the diploma students in the field of engineering/science and were registered during the academic year 2016-2017. The 400 sample was selected randomly among the students from the Malaysian Polytechnic Institutions. $66 \%$ male students and $34 \%$ female students. From the total, $19.3 \%$ of respondents made up of student from Department of Civil, 13.3\% were student of Department of Electrical, 24.3\% from Department Mechanical's students, 28.7\% from Department of Information Technology and Communication's student. While, other departments were 14.5\%. The selection of the samples was done using simple random sampling, while the sample size was determined using the sample size determination technique by [12].

\subsection{Instruments}

Data were collected using a questionnaire with a five-point scale. The respondent was required to respond the measurement items of educational technological tools with indicators started "strongly disagree" up to "strongly agree". Analysis of these data is done using IBM-SPSS version 21. The questionnaire items and the Cronbach's Alpha are shown in Table 1.

Table 1. Instruments information

\begin{tabular}{ccc}
\hline Item & No. Item & Cronbach's Alpha \\
\hline Educational Technological Tools & 12 Item & 0.932 \\
\hline
\end{tabular}




\subsection{Min Test}

Variation is the diversity of levels that researchers want to study. The descriptive stage described either the result was low, medium or high. For this variation, this factor is analyzed by mean, standard deviation and percentage. In this study, descriptive analysis is used to achieved min score and standard deviation to determine the research study about the usages of Facebook as educational technological tools in entrepreneurship course among students' polytechnics.

\section{RESULTS AND DISCUSSION}

From the findings in the Table 2, we can interpret the test results supported that the students gave a positive assessment, agree to use Facebook as an effective learning tools in the subjects of entrepreneurship. Hence, it shows the averages mean value scores for educational technology tools is on the approximate scale of 4.0 (3.93) from the 5-Likert scale that has been adopted.

It also shown that the item 'I became a Facebook member with ease' from the factor of perceived ease of use get the highest min; 3.9875. Students feel that if they do things easily then they will be more eager to complete the assignment given. Students can also socialize while learning something new in existing Facebook features. In terms of technical aspects of using Facebook, most of students did not have any problem at all because the students were familiar with the environment due to the fact that they were existing Facebook users.

The item of 'Facebook is similar to other social networks I use (MSN, e-mail, online forums)' record the lowest mean value, which is 3.72. In terms of social in Facebook that evidenced in the course and mentioned by students were the sharing, tagging and like button functions of Facebook that fostered informal interactions and learning in the course. By blending the formal and informal aspects of learning, students felt the activities were natural and welcoming for them to make posting without any hesitation or worry to make mistake. Maybe, the students assumed that Facebook are more attractive compared with another social networks such as msn, email or online forums. So, they cannot get found the similarities features readiness in Facebook. 
Table 2.Item analysis of using Facebook as an educational technology tools by response (\%) and mean

\begin{tabular}{|c|c|c|c|c|c|c|}
\hline \multirow{2}{*}{$\begin{array}{c}\text { Item } \\
\text { My lecturer in entrepreneurship subject ... }\end{array}$} & \multicolumn{5}{|c|}{ Responses (\%) } & \multirow[t]{2}{*}{ Mean } \\
\hline & $\begin{array}{l}\text { Strongly } \\
\text { disagree }\end{array}$ & Disagree & Neutral & Agree & $\begin{array}{c}\text { Strongly } \\
\text { agree }\end{array}$ & \\
\hline $\begin{array}{l}\text { 1. Allowed me to communicate with more } \\
\text { people in a short time period using Facebook. }\end{array}$ & 1.8 & 3.3 & 22.5 & 40.3 & 32.3 & 3.98 \\
\hline $\begin{array}{l}\text { 2. Allowed me to share more entrepreneurial } \\
\text { task in a short time period using Facebook. }\end{array}$ & 2.0 & 2.8 & 24.3 & 38.8 & 32.3 & 3.965 \\
\hline $\begin{array}{l}\text { 3. Makes it easier to establish and maintain } \\
\text { learning performance using Facebook. }\end{array}$ & 0.8 & 2.8 & 24.5 & 42.8 & 29.3 & 3.967 \\
\hline $\begin{array}{l}\text { 4. Generated new ideas to develop new services } \\
\text { marketing using Facebook. }\end{array}$ & 0.5 & 3.3 & 23.3 & 44.0 & 29.0 & 3.9775 \\
\hline
\end{tabular}

Rate your level of agreement with the following statements:

Strongly Disagree Neutral Agree Strongly Mean disagree agree

5. I became a Facebook member with ease.

1.3

1.8

24.3

42.5

30 .

3.9875

6. My interaction with my lecturer in Facebook

1.5

2.8

25.0

40.5

30.3

3.9525 is clear and understandable.

7. I do not have any problems learning 1.0 1.8 27.0 38.3 32.0 3.9850 entrepreneurship using Facebook features on my own.

8. I find it easy to use Facebook features to run 1.5 2.3 23.8 44.0 28.5 3.9575 entrepreneurship subject assignments.

9. I can learnt more about how to handling 1.3 2.5 23.0 45.3 28.0 3.9625 business when using Facebook features.

10. I can get technical support by email if I have problems using Facebook.

11. I can connect to Facebook where ever there 2.3 1.8 2.0 27.0 $41.3 \quad 28.0$ 3.9175 is Internet connectivity to handle my 
entrepreneurship simulations learning task.

12. Facebook is similar to other social networks $\quad \begin{array}{lllllll}6 & 4.5 & 28 & 34.5 & 27 & 3.72\end{array}$ I use (MSN, e-mail, online forums).

Numerous authors have admitted the necessity to conduct researched that analyze the use of social networking tools in educational contexts $[10-11,14,18]$.

The comprising of perceived usefulness, perceived ease of use and observable result in the constructs to evaluate the Facebook as an Educational Technology Tools are relevant accordingly to the underpinnings theories of this study using diffusion of innovation theories. In [22] is introduced as diffusion of innovation theory stating the different stages of adoption and correspondingly the different types of adopters according to the different characteristics of the readiness technology usages in educational context. In the current time, the technology plays a crucial role in teaching and learning.

Use of Facebook could help to link the period between the classroom and entrepreneurial practice as users continue to interact with the page after they have completed the course and encouraged into entrepreneurship. Educators should further assess use of Facebook as a method to increase student participation in online discussion of course content, evaluate the benefits and weaknesses of integrating coursework with social networking.

Use of Facebook as an educational technology tools to an entrepreneurship course was well received by Polytechnics' students. Therefore, it is considerably can increased their self-perceived likelihood of being exposed to course announcements, online discussions and external links [8]. Time to doing the assignment in entrepreneurial need were associated with the highest use of the course Facebook page.

\section{CONCLUSION}

Thus, empiricalstudy on Facebook as an educational technological tools are very essential to take note that learning was not directly measured, and positiveenvironments are required for Facebook to raise positive academic benefits [24]. As such, educators must decide whether reaching all students is more important than maximizing overall engagement.

Furthermore, a specific understanding of class demographics with respect to the number of students active on Facebook can help define which platforms to use in order to optimize 
independent engagement while using the tools.

\section{REFERENCES}

[1] Ghafar M. N. A. Reka bentuk tinjauan soal selidik pendidikan. Johor: Penerbit Universiti Teknologi Malaysia, 2003

[2] Aydin S. A review of research on Facebook as an educational environment. Educational Technology Research and Development, 2012, 60(6):1093-1106

[3] Azila B, Isrul H I, Nurul H S. Impak kursus digital entrepreneurship kepada pelajar Kolej Komuniti Wilayah Selangor.In E-Prosiding PASAK,2017, pp. 1-14

[4] Bosch T E. Using online social networking for teaching and learning: Facebook use at the University of Cape Town. Communicatio: South African Journal for Communication Theory and Research, 2009, 35(2):185-200

[5] Bumgarner B A. You have been poked: Exploring the uses and gratifications of Facebook among emerging adults. First Monday, 2007, 12(11):1-14

[6] Carini RM, Kuh GD, Klein SP. Student engagement and student learning: Testing the linkages. Research in Higher Education, 2006, 47(1):1-32

[7] Dabner N. 'Breaking Ground'in the use of social media: A case study of a university earthquake response to inform educational design with Facebook. The Internet and Higher Education, 2012, 15(1):69-78

[8] DiVall MV, Kirwin JL. Using Facebook to facilitate course-related discussion between students and faculty members. American Journal of Pharmaceutical Education. 2012, $76(2): 1-5$

[9] Goertler S. Using Computer-Mediated Communication (CMC) in language teaching. Die Unterrichtspraxis/Teaching German, 2009, 42(1):74-84

[10] Roblyer MD, McDaniel M, Webb M, Herman J, Witty JV. Findings on Facebook in higher education: A comparison of college faculty and student uses and perceptions of social networking sites. The Internet and Higher Education, 2010, 13(3):134-40

[11] Kabilan MK, Ahmad N, Abidin MJ. Facebook: An online environment for learning of English in institutions of higher education? The Internet and Higher Education, 2010, 13(4):179-187 
[12] Krejcie RV, Morgan DW. Determining sample size for research activities. Educational and Psychological Measurement, 1970, 30(3):607-610

[13] Kirschner PA, Karpinski AC. Facebook ${ }^{\circledR}$ and academic performance. Computers in Human Behavior, 2010, 26(6):1237-1245

[14] Lockyer L, Patterson J.Integrating social networking technologies in education: A case study of a formal learning environment. In 8th IEEE International Conference on Advanced Learning Technologies, pp. 529-533

[15] Irwin C, Ball L, Desbrow B, Leveritt M. Students' perceptions of using Facebook as an interactive learning resource at university. Australasian Journal of Educational Technology, 2012, 28(7):1221-1232

[16] Mason R. Learning technologies for adult continuing education. Studies in Continuing Education, 2006, 28(2):121-133

[17] Mazer JP, Murphy RE, Simonds CJ. I'll see you on "Facebook": The effects of computer-mediated teacher self-disclosure on student motivation, affective learning, and classroom climate. Communication Education, 2007, 56(1):1-7

[18] Mazman SG, Usluel YK. Modeling educational usage of Facebook. Computers and Education, 2010, 55(2):444-453

[19] McCarthy J. International design collaboration and mentoring for tertiary students through Facebook. Australasian Journal of Educational Technology,2012, 28(5):755-775

[20] Ministry of Education Malaysia (MOE).Annual report 2016: Malaysia Education Blueprint 2013-2025. Putrajaya: MOE, 2016

[21] Pasek J, Hargittai E. Facebook and academic performance: Reconciling a media sensation with data. First Monday, 2009, 14(5):1-14

[22] Rogers E. M. Diffusion of innovations. New York: Free Press, 1983

[23] Selwyn N. Faceworking: exploring students' education-related use of Facebook. Learning, Media and Technology, 2009, 34(2):157-174

[24] Souleles N. Perceptions of undergraduate Graphic Design students on the educational potential of Facebook. Research in Learning Technology, 2012, 20(3):241-252 
[25] Wang Q, Woo HL, Quek CL, Yang Y, Liu M. Using the Facebook group as a learning management system: An exploratory study. British Journal of Educational Technology, 2012, $43(3): 428-438$

How to cite this article:

Ali M M, Hashim N, Ibrahim A. The evaluations of facebook as an educational technology tools in polytechnic's entrepreneurship courses. J. Fundam. Appl. Sci., 2017, 9(6S), 805-815. 